\title{
PENGARUH PAPARAN GELOMBANG INFRASONIK (8-12 Hz) TERHADAP KECERDASAN DAN VISKOSITAS DARAH (HEMATOKRIT) MENCIT
}

\author{
Oleh: \\ Millatul Qomariyah ${ }^{1}$ dan Agus Mulyono ${ }^{2}$
}

\begin{abstract}
ABSTRAK:Kecerdasan merupakan suatu kemampuan yang dimiliki seseorang untuk memecahkan masalah dalam kehidupannya sehari-hari. Pada era globalisasi saat ini kecerdasan menjadi semakin penting agar mampu bersaing dengan yang lain. Ada banyak cara untuk meningkatkan kecerdasan seseorang salah satunya adalah dengan melatih gelombang otak. Gelombang otak yang sangat tepat untuk belajar dan meningkatkan kecerdasan adalah pada frekuensi $8-12 \mathrm{~Hz}$ dan termasuk range gelombang infrasonik. Selain itu, pemanfaatan gelombang otak pada frekuensi ini telah diaplikasikan di bidang kesehatan karena dapat menghilangkan depresi klinis pada pasien. Frekuensi gelombang infrasonik $(8-12 \mathrm{~Hz})$ tidak mudah untuk diciptakan namun dipasaran telah beredar kaset $\mathrm{CD}$ gelombang alfa. Sehingga aplikasi pemanfaatannya cukup mudah.Tujuan dari penelitian ini adalah untuk mengetahui pengaruh paparan frekuensi gelombang Infrasonik $(8-12 \mathrm{~Hz})$ terhadap peningkatan kecerdasan mencit dan untuk mengetahui pengaruh paparan frekuensi gelombang infrasonik $(8-12 \mathrm{~Hz})$ terhadap viskositas darah mencit. Pengujian kecerdasan pada penelitian ini menggunakan labirin yakni dengan melihat lama waktu yang dibutuhkan mencit untuk melewati labirin, semakin cepat mencit melewati labirin maka mencit semakin cerdas. Untuk mengetahui viskositas darah mencit dengan melihat himatokrit yaitu presentase darah yang berupa sel.Analisa dalam penelitian ini menggunakan Anova dengan taraf signifikansi $5 \%$. Diketahui bahwa gelombang infrasonik $(8-12 \mathrm{~Hz})$ mempengaruhi kecerdasan dengan nilai signifikansinya sebesar 0.000 , dan gelombang infrasonik (8$12 \mathrm{~Hz}$ ) juga mempengaruhi viskositas darah dengan nilai signifikansinya sebesar 0.000 .
\end{abstract}

Kata kunci : Gelombang Infrsonik, Kecerdasan dan Viskositas Darah

\begin{abstract}
Intelligence is ability of person to solve problems in their daily live. In globalization era intelligence is exceedingly important to compete with other. Moreover,the use of brain waves in this frequency has been applied in the medical field because it can cure clinical depression in patients.The frequency of infrasonic waves $(8-12 \mathrm{~Hz})$ is not easy to be created, but the $\mathrm{CD}$ alpha waves are traded. So the application is quite easy to use. The purpose of this study is to determine the effect of frequencies infrasonic wave $(8-12 \mathrm{~Hz})$ to increase mice's intelligence and determine the effect frequencies infrasonic wave $(8-12 \mathrm{~Hz})$ to the mice blood viscosity. Intelligence testing in this research by using a maze and looking at the time takes by mice to get through the maze, if the mice through a maze faster it shows mice's intelligence. To find out viscosity of the mice's blood is by looking at hematocrit, blood percentage which has cell shape. The analysis this research by using ANOVA with significance level of $5 \%$. It is known that infrasonic waves $(8-12 \mathrm{~Hz})$ affected intelligence with significance value of .000 , and infrasonic waves $(8-12 \mathrm{~Hz})$ affect blood viscosity with a significance value of .000 .
\end{abstract}

Keywords: infrasound wave (8-12 Hz), Intelligence, Blood Viscosity

\footnotetext{
${ }^{1}$ Mahasiswa Jurusan Fisika, Fakultas Sains dan Teknologi, UIN Maliki Malang (E-mail:Milla32@ymail.com)

${ }^{2}$ Staf Pengajar pada Jurusan Fisika, Fakultas Sains dan Teknologi, UIN Maliki Malang
} 


\section{PENDAHULUAN}

Kecerdasan merupakan suatu kemampuan yang dimiliki seseorang untuk mengatasi kesulitan dan masalah-masalah dalam hidup sehari-hari, dengan berfikir cepat dan tepat. Semakin tinggi kecerdasan seseorang maka akan lebih mudah menjalani hidup serta memiliki peluang besar untuk menjadi orang yang sukses.

Persaingan diera globalisasi ini sangat ketat sehingga kecerdasan manusia menjadi semakin penting agar mampu terus bersaing dengan yang lain. Kecerdasan bukanlah suatu yang dianugerahkan saja oleh Tuhan namun juga dapat diasah dan dibentuk. Sehingga setiap orang memiliki potensi yang sama, untuk memiliki keunggulan dalam hal kecerdasan agar mampu terus bersaing diera saat ini.

Menurut Badran (2013) secara umum ada dua faktor yang mempengaruhi kecerdasan seseorang yaitu faktor internal dan ekternal. Faktor internal merupakan faktor genetika sedangkan faktor ekternal merupakan lingkungan yang meliputi nutrisi, stimulasi, aktivitas fisik dan penjagaan kesehatan. Berdasarkan pendapat ini, maka faktor internal dapat dikenal sebagai "given" atau suatu anugerah dari Tuhan yang tidak bisa diotak atik dan faktor eksternal merupakan langkah-langkah yang dapat diupayakan untuk terus meningkatkan potensi dari anugerah tersebut [1].

Hasil penelitian menunjukkan bahwa kondisi ideal untuk belajar adalah ketika otak sedang dalam kondisi santai, namun tetap fokus dan terjaga atau lebih dikenal sebagai kondisi saat mengalami ketenangan. Kondisi ini sangat baik untuk belajar, menyerap informasi, melakukan terapi, mempercepat proses penyembuhan, meningkatkan kekebalan tubuh, juga mengurangi stress. Dalam keadaan ini gelombang otak berjalan sekitar 8 hingga 12 siklus per detik (8-12 Hz), yang dikenal dengan istilah kondisi alfa [2].

Menurut Iskandar (2008) Orang yang sedang melamun, tenang, rileks dan santai gelombang otaknya berada pada frekuensi gelombang alfa. Gelombang Alfa didefinisikan sebagai gelombang dengan frekuensi $8-12 \mathrm{~Hz}$ yang termasuk dalam range gelombang infrasonik [5]. Dalam kondisi gelombang alfa/infrasonik (8-12 Hz) akan timbul berbagai ide serta pemikiran yang positif. Hal ini penting untuk mengatasi masalah dan merangsang otak untuk menciptakan ide-ide yang lebih kaya. Kondisi otak alfa (8-12 Hz) juga merupakan pintu masuk atau akses kedalam fikiran bawah sadar, kondisi Inilah yang efektif untuk memasukkan informasi atau saran kedalam fikiran bawah sadar.

Banyak peneliti yang telah meneliti tentang gelombang alfa/infrasonik diantaranya adalah Ferriyansyah (2011) meyimpulkan bahwa Prestasi belajar matematika siswa yang dalam pembelajaran disertai dengan penciptaan kondisi alfa lebih baik daripada yang tidak disertai penciptaan kondisi alfa, [4]. menurut Suldo dkk (2002) frekuensi gelombang alfa/infrasonik ( 8-12 Hz) bisa mempercepat anak bisa membaca sebelum waktunya dan membuat otak menjadi cerdas [6], dan menurut Beahr dkk (2001) frekuensi gelombang alfa/infrasonik (8-12 Hz) dapat menghilangkan depresi klinis pada pasien [3] . Gelombang alfa/infrasonik (8-12 Hz) ini adalah gelombang otak yang dominan saat tubuh dan pikiran sedang beristirahat.Frekuensi gelombang infrasonik $(8-12 \mathrm{~Hz})$ tidak mudah untuk diciptakan namun dipasaran telah beredar kaset $\mathrm{CD}$ gelombang alfa.

Penelitian tentang pengaruh paparan gelombang infrasonik $(8-12 \mathrm{~Hz})$ terhadap peningkatan kecerdasan dan viskositas darah mencit (Mus Musculus) merupakan 
penelitian eksperimental yang menggunakan Rancangan Acak Kelompok dengan 4 perlakuan dan 5 ulangan. Perlakuan yang di gunakan adalah kontrol, pembacaan ayat alqur'an, pemutaran murottal Al-qur'an dan pemutaran musik terapi gelombang alfa.

Perlakuan pembacaan ayat al-qur'an, murottal al-qur'an dan musik gelombang alfa di berikan 30 menit setiap hari pada masing-masing kelompok mencit selama 6 minggu. Pengambilan sampel untuk pengamatan kecerdasan mencit dilakukan dengan langkah sebagai berikut : Hewan coba dimasukkan kedalam labirin yang telah disiapkan, kemudian dihitung waktu yang dibutuhkan mencit untuk keluar dari labirin dengan menggunakan stopwatch. Pengambilan Sampel untuk pengamatan viskositas darah (hematokrit) mencitdilakukan dengan langkah sebagai berikut: Hewan coba dianastesi secara inhalasi dengan menggunakan chloroform, lalu dibedah secara vertikal dari daerah abdomen posterior menuju anterior dengan membuka daerah rongga perut dan rongga dada, kemudian Diambil darah mencit dengan menggunakan spuit pada daerah jantung.dan ditunggu sampai darah pada spuit terpisah antara serum dan sel darah merah.

Data dianalisis dengan Analisis variansi (ANOVA) faktorial dengan taraf signifikansi $5 \%$ untuk mengetahui ada tidaknya pengaruh paparan frekuensi gelombang infrasonik $(8-12 \mathrm{~Hz})$ dan bacaan ayat-ayat alqur'an terhadap peningkatan kecerdasan mencit dan viskositas darah (Hematokrit) mencit.

\section{HASIL DAN PEMBAHASAN}

\section{Hasil Penelitian Pengaruh Paparan Gelombang Infrasonik (8-12 Hz) terhadap Kecerdasan Mencit.}

Dari analisis data menggunakan teknik analisis Anova Faktorial didapatkan data sebagai berikut:

Tabel 1. Hasil analisis statistik kecerdasan dengan metode ANOVA Faktorial

Dependent Variable:cerdas

\begin{tabular}{|c|c|c|c|c|c|}
\hline Source & $\begin{array}{c}\text { Type III Sum of } \\
\text { Squares }\end{array}$ & $\mathrm{df}$ & Mean Square & $\mathrm{F}$ & Sig. \\
\hline Model & $944190.000^{\mathrm{a}}$ & 24 & 39341.250 & 45.669 & .000 \\
\hline gelombang & 24249.500 & 3 & 8083.167 & 9.383 & .000 \\
\hline minggu & 13719.200 & 5 & 2743.840 & 3.185 & .011 \\
\hline gelombang * minggu & 7313.000 & 15 & 487.533 & .566 & .894 \\
\hline Error & 82698.000 & 96 & 861.438 & & \\
\hline Total & 1026888.000 & 120 & & & \\
\hline
\end{tabular}

a. R Squared $=.919($ Adjusted R Squared $=.899)$

Untuk mengetahui ada tidaknya pengaruh gelombang infrasonik terhadap kecerdasan mencit dapat dilakukan dengan melihat nilai signifikansi pada tabel, jika nilai signifikansi lebih kecildari 0,05 maka Ho ditolak yang berarti ada pengaruh jika nilai signifikansi lebih besar dari 0.05 maka Ho diterima yang berarti tidak ada pengaruh. Berdasarkan tabel 
diatas dapat diketahui bahwapengaruh gelombang infrasonik (8-12 Hz) terhadap kecerdasan diperoleh nilai signifikansinya sebesar 0.000 jadi ada pengaruh gelombang terhadap kecerdasan mencit.Dari tabel juga terlihat untuk lama pengulangan (minggu) diperoleh nilai signifikansinya sebesar 0.011 jadi ada pengaruh lama pemaparan (minggu) terhadap kecerdasan mencit. Dapat disimpulkan bahwa gelombang infrasonik berpengaruh terhadap kecerdasan mencit.Setelah menget ahui adanya pengaruh gelombang infrasonik (8-12 Hz) terhadap kecerdasan mencit maka dilanjutkan uji Duncan untuk mengetahui perlakuan yang paling efektif untuk meningkatkan kecerdasan.

Tabel 2.Hasil uji lanjut dengan uji Duncan.

\begin{tabular}{|c|c|c|c|}
\hline \multicolumn{4}{|c|}{ cerdas } \\
\hline \multicolumn{4}{|c|}{ Duncan $^{\mathrm{a}, \mathrm{b}}$} \\
\hline \multirow[b]{2}{*}{ gelombang } & \multirow[b]{2}{*}{$\mathrm{N}$} & \multicolumn{2}{|c|}{ Subset } \\
\hline & & 1 & 2 \\
\hline 4 & 30 & 76.4333 & \\
\hline 3 & 30 & 77.7333 & \\
\hline 2 & 30 & 81.0333 & \\
\hline 1 & 30 & & 111.0000 \\
\hline Sig. & & .572 & 1.000 \\
\hline
\end{tabular}

Berdasarkan hasil uji Duncan diatas dapat di ketahui bahwa mencit yang diberi perlakuan paparan gelombang infrasonik (8-12 Hz) didapatkan kecerdasan yang lebih tinggi dan signifikan jika dibandingkan dengan kelompok kontrol. Hanya saja perlakuan paparan gelombang infrasonik $(8-12 \mathrm{~Hz})$ dengan beberapa cara (tiga cara) tidak terdapat perbedaan yang signifikan.

\section{Pengaruh Paparan Gelombang Infrasonik (8-12 Hz) terhadap Viskositas Darah (Hematokrit) Mencit}

Dari analisis data menggunakan teknik analisis Anova Faktorial didapatkan data sebagai berikut:

Tabel 3. Hasil analisis statistik viskositas darah dengan metode ANOVA Faktorial

Tests of Between-Subjects Effects

\begin{tabular}{lrrrrr}
\hline \multicolumn{6}{c}{ Dependent Variable:viskos } \\
\hline Source & $\begin{array}{c}\text { Type III Sum } \\
\text { of Squares }\end{array}$ & df & Mean Square & \multicolumn{1}{c}{ F } & \multicolumn{1}{c}{ Sig. } \\
\hline Model & $42.405^{\mathrm{a}}$ & 24 & 1.767 & 53.985 & .000 \\
gelombang & .338 & 3 & .113 & 3.446 & .020 \\
minggu & .042 & 5 & .008 & .259 & .934 \\
gelombang * minggu & .312 & 15 & .021 & .635 & .839 \\
Error & 3.142 & 96 & .033 & &
\end{tabular}


Total $\quad 45.547 \quad 120$

a. R Squared $=.931($ Adjusted $\mathrm{R}$ Squared $=.914)$

Untuk mengetahui ada tidaknya pengaruh gelombang infrasonik $(8-12 \mathrm{~Hz})$ terhadap viskositas darah mencit dapat dilakukan dengan melihat nilai signifikansi pada tabel, jika nilai signifikansi lebih kecil dari 0,05 maka Ho ditolak yang berarti ada pengaruh dan jika nilai signifikansi lebih besar dari 0.05 maka Ho diterima yang bererti tidak ada pengaruh. Berdasarkan tabel diatas dapat diketahui bahwa pengaruh gelombang infrasonik (8-12 Hz) terhadap viskositas darah diperoleh nilai signifikansinya sebesar 0.000 jadi ada pengaruh gelombang terhadap viskositas darah mencit. Dari tabel juga terlihat untuk lama pengulangan (minggu) diperoleh nilai signifikansinya sebesar 0.020 jadi ada pengaruh lama pemaparan (minggu) terhadap viskositas darah mencit.. Dapat disimpulkan bahwa gelombang infrasonik berpengaruh terhadap viskositas darah mencit.

Setelah mengetahui adanya pengaruh gelombang infrasonik $(8-12 \mathrm{~Hz})$ terhadap viskositas darah mencit maka dilanjutkan uji Duncan untuk mengetahui perlakuan yang paling efektif untuk menstabilkan viskositas darah.

Tabel 4.Hasil uji lanjut dengan uji Duncan.

\begin{tabular}{|c|c|c|c|}
\hline \multicolumn{4}{|c|}{ Viskos } \\
\hline \multicolumn{4}{|c|}{ Duncan $^{\mathrm{a}, \mathrm{b}}$} \\
\hline \multirow{2}{*}{ Gelombang } & \multirow{2}{*}{$\mathrm{N}$} & \multicolumn{2}{|c|}{ Subset } \\
\hline & & 1 & 2 \\
\hline 1 & 30 & .5000 & \\
\hline 4 & 30 & & .6000 \\
\hline 2 & 30 & & .6267 \\
\hline 3 & 30 & & .6317 \\
\hline Sig. & & 1.000 & .528 \\
\hline
\end{tabular}

Berdasarkan hasil uji Duncan diatas dapat di ketahui bahwa mencit yang diberi perlakuan paparan gelombang infrasonik $(8-12 \mathrm{~Hz})$ didapatkan viskositas yang signifikan jika dibandingkan dengan kelompok kontrol. Hanya saja perlakuan paparan gelombang infrasonik (8-12 Hz) dengan beberapa cara (tiga cara) tidak terdapat perbedaan yang signifikan.

\section{KESIMPULAN}

Berdasarkan hasil penelitian dan pembahasan yang telah diuraikan, dapat diambil kesimpulan sebagai berikut:

1. Gelombang infrasonik $(8-12 \mathrm{~Hz})$ dapat meningkatkan kecerdasan mencit. Paparan gelombang infrasonik (8-12 Hz) pada mencit akan memberikan rangsangan (Stimulus) terhadap neuron, kemudian di dalam neuron akan terjadi potensial aksi 
di sepanjang akson hingga membuat glutamat lepas dari akson dan diterima oleh reseptor glutamat. Di dalam reseptor glutamat, glutamat akan mengaktivasi NMDA hingga menghasilkan efek seluler yakni memicu signaling dalam learning dan memori, sehingga kecerdasan mencit menjadi meningkat.

2. Gelombang infrasonik $(8-12 \mathrm{~Hz})$ dapat berpengaruh terhadap viskositas darah (Hematokrit) mencit.

\section{DAFTAR PUSTAKA}

[1] Badran,Ahmad. 2010. Cara cerdas mencerdaskan otak. Solo: Pustaka Iltizam

[2] Barrett, Bruce, dkk 2012. Meditation or Exercise for Preventing Acute Respiratory Infection: A Randomized Controlled Trial. Annal Journals Club. Vol.10. No. 4 337346.

[3] Beahr, Else dkk.2001. Clinical Use Of An Alpha Asymmetry Neurofeedback Protokol In The Tretment Of Mood Disorders. Jurnal Of Neurotherapy. Vol.4. Issue 4.

[4] Ferriyansyah, 2011. Perbandingan Prestasi Belajar Matematika Siswa Antara Pembelajaran yang disertai penciptaan kondisi alpha. Volume 3 Nomor 2

[5] Iskandar, Alex dan Endi Novianto, 2008. Meditate and Grow Rich. Terjemahan, Jakarta: PT Gramedia,

[6] Suldo, Shannon M dkk.2002. Quantitativ EEg Ahdence Of Increased Alpha Peak Frequency In Children With Precocius Reading Ability:Journal Of Neurotherapy. Volume 5. Issu 3. 